\title{
ENTREPRENEURSHIP BAGI MAHASISWA: ANTARA BISNIS DAN KEBUTUHAN HIDUP (STUDI KASUS MAHASISWA STIT AL-AMIN KREO TANGERANG)
}

\author{
PARHANA \\ MA. Jam'iyyah Islamiyyah Tngerang Selatan \\ Parhana73@gamil.com
}

\begin{abstract}
ABSTRAK
Penelitian ini berjudul Enterpreneurship Bagi Mahasiswa: Antara Bisnis dan Kebutuhan Hidup (Studi Kasus Mahasiswa Sekolah Tinggi Ilmu Tarbiah Al-Amin Kreo Tangerang) . Penelitian ini menggunakan metode kualitatif dengan tujuh narasumber mahasiswa yang masih aktif berkuliah serta melakukan aktivitas bisnis. Penelitian fokus pada latar belakang mahasiswa berwirausaha ditinjau dari lingkungan pendidikan, ekspektasi pendapatan, dan motivasi. Penelitian juga membahas tentang proses mahasiswa dalam menciptakan usahanya. Temuan dalam penelitian ini menunjukan bahwa mahasiswa wirausahawan memilih untuk berwirausaha karena pengaruh latar belakang motivasi untuk memenuhi kebutuhan hidup mereka. Faktor eksternal seperti lingkungan keluarga, pendidikan, ekspektasi pendapatan memiliki peran dalam mendorong intensi berwirausaha mahasiswa. Mahasiswa menciptakan usaha yang mudah untuk dijalankan sambil berkuliah. Mahasiswa wirausahawan menciptakan usaha dengan ide yang berasal dari realita kehidupan seharihari dan dari passion atau hobi mereka. Mereka membutuhkan partner dalam membangun usahanya. Dalam proses menciptakan usaha mahasiswa memiliki hambatan seperti keterbatasan modal, keterbatasan waktu dan pengelolaan awal usaha yang masih kacau.

Kata Kunci: Kewirausahaan, Bisnis, Kebutuhan Hidup
\end{abstract}

\begin{abstract}
This research is entitled Entrepreneurship for Students: Between Business and Life Needs (Case Study of Tarbiah Al-Amin Kreo High School Student Tangerang). This study uses a qualitative method with seven student informants who are still active in college and doing business activities. The study focused on the background of entrepreneurship students in terms of the educational environment, income expectations, and motivation. Research also discusses the process of students in creating their business. The findings in this study indicate that entrepreneurial students choose to become entrepreneurs because of the influence of motivational backgrounds to meet their daily needs. External factors such as family environment, education, income expectations have a role in encouraging student entrepreneurship intentions. Students create businesses that are easy to run while studying. Student entrepreneurs create businesses with ideas that come from the realities of everyday life and from their passion or hobbies. They need partners in building their businesses. In the process of creating business students have obstacles such as limited capital, limited time and the initial management of a business that is still chaotic.
\end{abstract}

Keywords: Entrepreneurship, Business, Life Needs 


\section{A. PENDAHULUAN}

Kebijakan pemerintah yang berpihak pada pengembangan budaya kewirausahaan sudah dimulai sejak tahun 1995 dan terus berkembang hingga kini. ${ }^{1} \mathrm{Di}$ awal kebijakan tersebut Presiden Republik Indonesia (RI) saat itu menginstruksikan kepada seluruh masyarakat dan bangsa Indonesia untuk mengembangkan programprogram kewirausahaan. Sejak saat itu gerakan pendidikan kewirausahaan mulai diprogramkan oleh berbagai organisasi, baik organisasi bidang pendidikan dasar, menengah dan pendidikan tinggi, serta organisasi pemerintah dan swasta. Melalui gerakan ini diharapkan budaya kewirausahaan dapat menjadi bagian etos kerja masyarakat dan bangsa Indonesia, yang pada akhirnya dapat dilahirkan wirausahawirausaha baru yang andal, tangguh dan mandiri. ${ }^{2}$

Dewasa ini, banyak perguruan tinggi di Indonesia yang telah memasukkan mata kuliah kewirausahaan ke dalam kurikulum mereka sebagai salah satu mata kuliah pokok yang wajib diikuti oleh seluruh mahasiswa. ${ }^{3}$ Pendidikan kewirausahaan tidak hanya memberikan landasan teoretis mengenai konsep kewirausahaan tetapi membentuk sikap, perilaku, dan pola pikir (mindset) seorang wirausahawan (entrepreneur). ${ }^{4} \mathrm{Hal}$ ini merupakan investasi modal manusia untuk mempersiapkan para mahasiswa memulai bisnis baru melalui integrasi pengalaman, keterampilan, dan pengetahuan penting untuk mengembangkan dan memperluas sebuah bisnis. ${ }^{5}$ Pendidikan kewirausahaan juga dapat meningkatkan minat para mahasiswa untuk memilih kewirausahaan sebagai salah satu pilihan karier selain pilihan karier menjadi pegawai swasta, PNS, atau pegawai BUMN di mana secara signifikan dapat mengarahkan sikap, perilaku, dan minat ke arah kewirausahaan. ${ }^{6}$

Sejak dicanangkannya pendidikan kewirausahaan hingga saat ini, subtansi dari model pendidikan ini banyak mendiskusikan atau seringkali dikonotasikan dengan pendidikan bisnis. Hal ini dapat dilihat dari kurikulum pendidikan kewirausahaan yang disiapkan oleh sebagian besar penyelenggara pendidikan kewirausahaan. Kurikulum pendidikan kewirausahaan umumnya berisi materi dan aktivitas yang berhubungan dengan membangun sikap mental kewirausahaan, melatih keterampilan berkomunikasi, membangun jejaring dan menyusun rencana bisnis yang berorientasi pada keuntungan. Oleh karena itu tidaklah mengherankan ketika suatu perguruan

${ }^{1}$ Susilaningsih, "Pendidikan Kewirausahaan Di Perguruan Tinggi: Penting kah Untuk Semua Profesi?" Jurnal Economia, Vol. 11, No. 1 (2015): 1-9.

${ }^{2}$ Instruksi Presiden, “Instruksi Presiden Nomor 4 tahun 1995 Tentang Gerakan Nasional Memasyarakatkan Dan Membudayakan Kewirausahaan", (2015): 1-15.

3 Ari Dian Saputra dan Susena, "Kontribusi Mata Kuliah Kewirausahaan dalam Menumbuhkan Jiwa Entrepreneurship yang Beretika pada Mahasiswa Prodi PPKn FKIP UAD Yogyakarta", Jurnal Citizenship, Vol. 2 No. 1, (2013): 41-48.

${ }^{4}$ Dwi Wahyu Pril Ranto, "Membangun Perilaku Entrepreneur Pada Mahasiswa Melalui Entrepreneurship Education", JBMA, Vol. III, No. 1 (2016): 79-86.

${ }^{5}$ Kourilsky dan Walstad," Entrepreneurship and Female Youth: Knowledge, Attitudes, Gender Differences and EducationalPractices", Journal of Business Venturing, Vol. 13, No. 1, (1998): 7788.

${ }^{6}$ Retno Budi Lestari, Trisnadi Wijaya," Pengaruh Pendidikan Kewirausahaan Terhadap Minat Berwirausaha Mahasiswa di STIE MDP, STMIK MDP, dan STIE MUSI", Forum Bisnis dan Kewirausahaan Jurnal Ilmiah STIE MDP, Vol. 1, No. 2, (2012): 113. 
tinggi mewajibkan mata kuliah kewirausahaan bagi seluruh mahasiswanya. ${ }^{7}$ Optimisme, sikap nilai dan status kewirausahaan atau keberhasilan ${ }^{8}$ Keberhasilan wirausahawan ditentukan oleh perilaku kewirausahaan. ${ }^{9}$ Perilaku kewirausahaan dipengaruhi oleh faktor internal dan faktor eksternal, faktor internal yaitu hak kepemilikan, kemampuan/kompetensi dan insentif, sedangkan faktor eksternal meliputi lingkungan, dimana faktor yang berasal dari lingkungan di antaranya adalah kebijakan pemerintah, model peran, peluang, pesaing, dan sumber daya. ${ }^{10}$

Wirausaha merupakan orang yang menciptakan sebuah bisnis yang berhadapan dengan risiko dan ketidakpastian, bertujuan memperoleh profit dan mengalami pertumbuhan dengan cara mengidentifikasi kesempatan dan memanfaatkan sumber daya yang diperlukan. Dewasa ini, banyak kesempatan untuk berwirausaha bagi setiap orang yang jeli melihat peluang bisnis tersebut. Karier kewirausahaan dapat mendukung kesejahteraan masyarakat yaitu menghasilkan imbalan finansial yang nyata. ${ }^{11}$

Fenomena entrepreneur di kalangan anak muda dalam beberapa tahun terakhir semakin populer. Apalagi, dengan banyaknya seminar motivasi, buku-buku bacaan serta pemberitaan yang mengupas seputar kesuksesan pelaku usaha sehingga mendorong mereka untuk terjun dalam dunia bisnis. ${ }^{12}$ Bisnis di kalangan mahasiswa kini sangat menjamur, selain menjadi mata kuliah pilihan di berbagai Fakultas. Hal ini seakan sudah menjadi tren, istilahnya "gak bisnis gak keren". Skalanya pun bervariasi, dari yang kecil-kecilan seperti jualan pulsa sampai yang besar seperti membuat koskosan. Keinginan mahasiswa tersebut memang beragam, ada yang memang ingin serius bisnis karena untuk mencukupi kebutuhan, ikut-ikutan, mengisi waktu luang dan sebagainya. ${ }^{13}$

Agar bisnis dapat berkembang, maka harus dikelola dengan baik. Rasulullah SAW telah memberikan contoh yang dapat diteladani dalam berbisnis yaitu: 1;Kejujuran, 2;Keadilan, 3;Barang atau produk yang dijual haruslah barang yang halal, baik dari segi dzat nya maupun cara mendapatkannya, dan 4; Tidak ada unsur penipuan. Selain itu, bisnis harus dilakukan berdasarkan etika. Etika bisnis dalam syari'ah Islam adalah akhlak dalam menjalankan bisnis sesuai dengan nilai-nilai Islam dan sebagai rambu-rambu dalam melakukan transaksi agar tetap berjalan dalam

${ }^{7}$ Susilaningsih," Pendidikan Kewirausahaan di Perguruan Tinggi: Pentingkah Untuk Semua Profesi?", Jurnal Ekonomia, Vol. 11, No. 1, (2015): 3.

8 Hendro mengatakan bahwa terdapat faktor-faktor yang mempengaruhi minat berwirausaha, salah satunya adalah pendidikan. Pendidikan yang dimaksud adalah pendidikan kewirausahaan. Hendro, Dasar-dasar Kewirausahaan (Jakarta: Erlangga, 2011), 62.

'Suryana, Kewirausahaan: Pedoman Praktis, Kiat dan Proses Menuju Sukses (Jakarta: Salemba Empat, 2013), 109.

${ }^{10}$ Hendro, Dasar-dasar Kewirausahaan (Jakarta: Erlangga, 2011), 61-63.

${ }^{11}$ Agustina, C., \& Sularto, L, "Intensi kewirausahaan mahasiswa (Studi perbandingan antara fakultas ekonomi dan fakultas ilmu komputer)", Proceeding PESAT (Psikologi, Ekonomi, Sastra, Arsitektur, E Sipil) Universitas Gunadarma, Vol. 4, (2011): 63-69.

12 Adi Susanto, Kewirausahaan, Ghalia Indonesia, (Jakarta: Ghalia Indonesia, 2000) h. 38.

${ }^{13}$ Slamet Raharjo, Motivasi Mahasiswa dalam Berbisnis, Warta Wirausaha, 26 Februari 2013, 
koridor nilai-nilai Islam sehingga dalam melaksanakan bisnisnya tidak perlu ada kekhawatiran, sebab diyakini sebagai sesuatu yang baik dan benar. ${ }^{14}$

Menjadi seorang entrepreneur adalah sebuah pilihan menjalankan bisnis untuk memenuhi kebutuhan hidup, karena sebagian dari mereka menjalankan bisnis untuk bisa membiayai pendidikan kuliah dengan hasil usahanya sendiri dan membiaskan hidup mandiri tanpa ingin membebani orang lain. ${ }^{15}$ Sebagaimana di ketahui bahwa alQur'an adalah sumber nilai sumber dari segala sumber untuk pegangan hidup umat Islam. Maka terkait itu, al-Qur'an telah membicarakan bisnis, sekaligus merupakan bukti bahwa Islam memberikan perhatian terhadap bisnis sebagai prata sosial. Bahkan al-Qur'an juga memotivasi usaha komersial dan perdagangan dengan cara memberikan keberanian atau semangat untuk berwiraswasta. ${ }^{16}$ Dalam al-Qur'an, bisnis dijelaskan melalui kata "tijarah" yang mencakup dua makna, yaitu: pertama, perniagaan secara umum yang mencakup perniagaan antara manusia dengan Allah. Ketika seseorang memilih petunjuk dari Allah, mencintai Allah dan Rasul-Nya, berjuang di jalan-Nya dengan harta dan jiwa, membaca kitab Allah, mendirikan salat, menafkahkan sebagian rezekinya, maka itu adalah sebaik-baiknya perniagaan antara manusia dengan Allah. Dalam salah satu ayat al-Qur'an dijelaskan bahwa ketika seseorang membeli petunjuk Allah dengan keesaan, maka ia termasuk seseorang yang beruntung.

Terkait entrepreneurship mahasiswa yang dijalankannya sambil berkuliah maka peneliti mewawancarai salah satu mahasiswa Sekolah Tinggi Ilmu Tarbiah Al-Amin Kreo Tangerang. Sebut saja Narasumber C, C mulai berbisnis "Warung Nasi Sambal Gledek" sejak semester 7 (tujuh) di toko sekitar kawasan jalan pesantren pada sore hingga malam hari. Pemilihan brand produknya pun berasal dari namanya sendiri agar lebih mudah dikenal. Sebelum berjualan ayam goreng di Warung Sambal Geledek, C sempat berjualan buah-buahan. Semenjak semester 1 (satu), C memang sudah bekerja di salah satu perusahaan jasa pembersih ruangan sebagai asisten manager. Namun, pekerjaan tersebut tidak berlangsung lama karena ternyata mengganggu waktu kuliahnya. ${ }^{17}$ Alasan kenapa $\mathrm{C}$ mulai berbisnis adalah karena desakan kebutuhan hidup, bagaimana ia bisa memperoleh pendapatan atau gaji tanpa harus mengganggu kuliahnya. Dari sini, C memutuskan untuk berbisnis. Bisnis yang sampai sekarang masih ia tekuni adalah usaha warung sambal geledeknya. Usahanya ini sudah berjalan lebih dari satu tahun, dan dari usahanya itu ia bisa membiayai kuliahnya sendiri bahkan bisa membeli barang-barang yang dapat menunjang perkuliahan, seperti sepeda motor, laptop, modem, dan lain-lain.

Bisnis sambal geledeknya ia kelola sendiri dan pemilihan lokasi bisnisnya adalah lokasi yang dekat dengan konsumen (mahasiswa dan masyarakat umum) serta

${ }^{14}$ Akhmad Nur Zaroni, "Bisnis dalam Perspektif Islam”, Mazahib IV, Vol. 4, No. 2, (2007): 178179.

15 Josia Sanchaya Hendrawan, Hani Sirine, "Pengaruh Sikap Mandiri, Motivasi, Pengetahuan Kewirausahaan Terhadap Minat Berwirausaha (Studi Kasus pada Mahasiswa FEB UKSW Konsentrasi Kewirausahaan)", AJIE , Vol. 02, No. 3, (2017): 292.

16 Abdul Aziz, Etika Bisnis Perspektif Islam: Implementasi Etika Islam untuk Dunia Usaha (Bandung: AL-Fabeta, 2013), 97-100.

17 Mata kuliah kewirausahaan diberikan di berbagai program studi baik yang berbasis ekonomi maupun program studi lainnya. Eriawaty dan Fitriyanti, "Peran Mata Kuliah Kewirausahaan dalam Menumbuhkan Jiwa Wirausaha Mahasiswa Pendidikan Ekonomi", Jurnal Profit, Vol. 3, No. 3, (2016): 3. 
dapat dijangkau dengan mudah. $\mathrm{C}$ memasok persediaan ayamnya dan bahan-bahan lainnya dari Pasar Tradisional. Modal awal berasal dari hasil usaha bisnis dan gaji yang sebelumnya ia peroleh. Promosi dilakukan melalui media sosial dan dari mulut ke mulut, khususnya antar-mahasiswa STIT Al-Amin Kreo Tangerang. Sedangkan untuk kemampuan kewirausahaannya ia dapatkan dari proses perjalanan bisnisnya karena dilakukan secara otodidak.

Terkait dengan persoalan diatas, peneliti membahas entrepreneurship di kalangan mahasiswa sebagai bisnis dan kebutuhan hidup serta kaitan nya dengan pendidikan. Hal ini mengingat sudah banyak dikalangan mahasiswa yang berkecimpung di dunia kewirausahaan yang menjadikannya sebagai bisnis dan kebutuhan hidup. Penelitian ini mengambil studi kasus. Sebagai salah satu varian dalam penelitian kualitatif, studi kasus memberikan uraian dan penjelasan komprehensif mengenai suatu setting tertentu, dokumen, atau suatu kejadian tertentu. ${ }^{18}$

Berdasarkan latar belakang diatas, peneliti mengidentifikasi beberapa permasalahan sebagai berikut: 1) Terdapat mahasiswa yang melakukan aktivitas bisnis di kalangan mahasiswa STIT Al-Amin Kreo Tangerang; 2) Kecenderungan mahasiswa STIT Al-Amin menjalankan entrepreneurship saat masih menjalankan pendidikan di bangku kuliah; 3) Korelasi bisnis dengan kebutuhan hidup mahasiswa. Penelitian ini membataskan bahasannya pada aktivitas entrepreneurship pada mahasiswa Sekolah Tingi Ilmu Tarbiah (STIT) Al-Amin Kreo Tangerang.

\section{B. METODE PENELTIAN}

Dalam membahas aktivitas entrepreneurship mahasiswa STIT Al-Amin Kreo Tangerang, penelitian ini menggunakan pendekatan kualitatif. Sebab dalam penelitian kualitatif, peneliti mengkaji sesuatu dalam setting natural dan menafsirkan fenomena terkait dengan makna. Penelitian kualitatif sebagaimana yang dikatakan oleh Sharan B. Merriam, memiliki empat karakteristik utama yaitu: 1) Menekankan pada proses, pemahaman, dan makna; 2) Peneliti berfungsi sebagai instrumen utama dalam pengumpulan dan analisis data; 3) Proses bersifat induktif; 4) Hasilnya bersifat deskripsi yang kaya. ${ }^{19}$

Penelitian Kualitatif bersifat induktif, peneliti membiarkan permasalahanpermasalahan muncul dari data atau dibiarkan terbuka untuk interpretasi. Data dihimpun dengan pengamatan yang saksama, mencakup deskripsi dalam konteks yang mendetail disertai catatan-catatan hasil wawancara yang mendalam, serta hasil analisis dokumen dan catatan-catatan. Penelitian kualitatif mempunyai dua tujuan utama, yaitu 1) Menggambarkan dan mengungkapkan (to describe and explore); 2) Menggambarkan dan menjelaskan (to describe and explain). Berdasarkan tujuan yang ingin dicapai itulah maka penelitian kualitatif menggunakan instrumen pengumpulan data yang sesuai dengan tujuannya. ${ }^{20}$ Dalam menganalisis data, penelitian ini mengacu pada prosedur analisis data Milles dan Hubermen. Menurut Milles dan Hubermen,

${ }_{18}$ Robert Bogdan Biklen, Sari Knopp, Qualitative Research for Education: An Introduction to Theory and Methods (Boston: Allyn and Bacon), 54.

${ }^{19}$ Sharan B. Merriam, Qualitative Research: A Guide to Design and implementation (USA: The Jossey-Bass, 2009), 13-14.

${ }^{20}$ Bachtiar. S Bachri, "Meyakinkan Validitas Data Melalui Triangulasi Pada Penelitian Kualitatif", Jurnal Teknologi Pendidikan, Vol. 10, No. 1, (2010): 50. 
analisis data dalam penelitian kualitatif, secara umum dimulai sejak pengumpulan data, reduksi data, penyajian data, dan penarikan kesimpulan atau verifikasi. Unsurunsur metodologi dalam prosedur ini sekaligus mencerminkan komponen-komponen analisis yang bersifat interaktif. ${ }^{21}$

Kegiatan analisis selama pengumpulan data dimaksud untuk menetapkan fokus di lapangan, menyusun temuan sementara, pembuatan rencana pengumpulan data berikutnya, pengembangan pernyataan-pernyataan analitis dan penetapan sasaran-sasaran data berikutnya. Kemudian dari pengumpulan data (data collection) tersebut, direduksi (data reduction) sebagai upaya pemilihan pemusatan perhatian pada penyederhanaan, dan mengabstrakkan data-data lapangan. ${ }^{22}$ Kemudian dari Sebab dalam penelitian kualitatif, peneliti mengkaji sesuatu dalam setting natural dan menafsirkan fenomena terkait dengan makna. Adapun metode yang digunakan dalam penelitian ini adalah metode studi kasus. Sebagai salah satu varian dalam penelitian kualitatif, studi kasus memberikan uraian dan penjelasan komprehensif mengenai suatu setting tertentu. ${ }^{23}$

Beberapa jenis observasi partisipan, mulai dari orientasi yang paling aktif sampai yang paling pasif adalah cara peneliti memposisikan diri saat melakukan penelitian kualitatif. Namun, observasi partisipan tidak dengan sendirinya merupakan metode pengumpulan data. Peneliti masih harus melakukan beberapa kegiatan khusus untuk mengumpulkan data:

\section{Interview atau wawancara terstruktur.}

Wawancara dapat berlangsung dalam berbagai bentuk, namun demi menjaga argumen, maka penulis dapat mempertimbangkan semua bentuk ke dalam wawancara terstruktur. Semua wawancara melibatkan interaksi antara pewawancara dan peserta (atau orang yang diwawancarai). Wawancara terstruktur dengan hati-hati menuliskan interaksi. Dalam metode wawancara ini peneliti akan menggunakan kuesioner formal yang mencantumkan setiap pertanyaan yang harus ditanyakan. Kedua, peneliti secara formal akan mengadopsi peran pewawancara, mencoba mendapatkan tanggapan dari orang yang diwawancarai. Ketiga, peneliti sebagai pewawancara akan mencoba untuk mengadopsi perilaku dan perilaku konsisten yang sama saat mewawancarai setiap peserta.

\section{Observation}

Observasi menjadi cara yang sangat berharga untuk mengumpulkan data karena apa yang dilihat dengan mata kepala sendiri dan dirasakan dengan indra sendiri yang mungkin tidak dilihat orang lain. Observasi ialah studi yang disengaja dan sistematis tentang fenomena sosial dan gejala-gejala psikis dengan jalan pengamatan dan pencatatan. Selanjutnya dikemukakan tujuan observasi ialah mengerti ciri-ciri dan luasnya signifikansi dari interelasinya elemen-elemen tingkah laku manusia pada

${ }_{21}$ Milles M. Hubermen and dan Michael, Analisis data Kualitatif (Jakarta: Universitas Indonesia, 1992), 92.

22 Saihu, "Pendidikan Karakter Berbasis Kearifan Lokal" (Studi di Jembrana Bali)', Jurnal Pendidikan Islam, Vol. 8, No. 1, (2019): 77-78.

${ }^{23}$ Robert Bogdan Biklen, Sari Knopp, Qualitative Research for Education: An Introduction to Theory and Methods (Boston: Allyn and Bacon), 54. 
fenomena sosial serba kompleks dalam pola-pola kultur tertentu Observasi yang dilakukan dalam penelitian ini meliputi melihat lokasi penelitian yaitu beberapa tempat aktivitas mahasiswa di Sekolah Tingi Ilmu Tarbiah (STIT) Al-Amin Kreo Tangerang dan melihat langsung kegiatan usaha yang sedang dijalani dan dikelola oleh mahasiswa tersebut. Untuk menetapkan keabsahan data, diperlukan teknik pemeriksaan. Pelaksanaan teknik pemerikasaan didasarkan pada sejumlah kriteria tertentu. Ada empat kriteria yang digunakan, yaitu derajat kepercayaan (kredibilitas), keteralihan (transferbility), ketergantungan (dependability), dan kepastian (confirmability).

Teknik analisis data Menurut Moleong, ada tiga model analisis data kualitatif, yaitu metode perbandingan tetap yang ditemukan oleh Glaser dan Strauss, yang kedua model analisis data menurut Spradley, dan yang ketiga adalah analisis data menurut Miles dan Huberman. ${ }^{24}$ Dalam penelitian ini analisis data menggunakan model Miles dan Huberman. Analisis data dilakukan pada saat pengumpulan data berlangsung dan setelah selesai pengumpulan data dalam periode tertentu. Aktivitas dalam analisis data pada penelitian ini meliputi:

\section{Reduksi Data}

Data yang diperoleh dari lapangan jumlahnya cukup banyak maka perlu dicatat secara rinci dan teliti. Semakin lama peneliti di lapangan, maka jumlah data akan semakin banyak. Untuk itu perlu segera dilakukan analisis data melalui reduksi data. Mereduksi data berarti merangkum, memilih hal-hal yang pokok, memfokuskan kepada hal-hal yang penting, dicari tema dan polanya. Dalam penelitian ini reduksi dilakukan dengan mengumpulkan data, memilih data yang penting, memberi kode pada data tersebut dan meringkasnya dalam bentuk tabel reduksi.

\section{Penyajian Data}

Dalam penelitian kualitatif penyajian data ini dapat dilakukan dalam bentuk tabel, grafik, phie chard, pictogram dan sejenisnya. Melalui penyajian data tersebut, maka data akan terorganisasi, tersusun dalam pola hubungan, sehingga akan semakin mudah dipahami. Dalam penelitian ini penulis membuat penyajian data ke dalam bentuk narasi dan diringkas dalam bentuk diagram alur. Menarik Kesimpulan Langkah selanjutnya dalam analisis data kualitatif adalah penarikan kesimpulan dan verifikasi. Kesimpulan awal yang dikemukakan masih bersifat sementara dan akan berubah bila tidak ditemukan bukti-bukti yang kuat yang mendukung pada tahap pengumpulan data berikutnya. Hal yang dilakukan penulis yaitu menarik kesimpulan dari hasil penelitian yang sudah ditemukan dan disesuaikan dengan rumusan masalah penelitian.

\section{HASIL DAN PEMBAHASAN}

1. Latar Belakang Entrepreneurship Mahasiswa Sekolah Tinggi Ilmu Tarbiah AlAmin Kreo Tangerang

Saat ini mahasiswa tidak lagi hanya berperan sebagai seorang penuntut ilmu dan aktivis kampus. Kemajuan teknologi, kemudahan mendapatkan informasi dan

${ }^{24}$ Moleong, Lexy, J., Metodologi Penelitian Kualitatif Edisi Revisi (Bandung: PT. Remaja Rosdakarya, 2005), 47. 
kondisi pasar menjadi suatu potensi yang dapat dimanfaatkan oleh mahasiswa untuk berwirausaha. Sekarang banyak mahasiswa yang telah terjun kedalam dunia bisnis dan mereka lakukan sambil belajar di kampus. Mahasiswa memanfaatkan apa saja yang dapat menunjang kemajuan bisnis mereka. Mereka membuat usaha dengan berbagai alasan yang menguatkan niatnya. Sekolah Tinggi Ilmu Tarbiah Al-Amin Kreo Tangerang sebagai salah satu perguruan tinggi yang ada di Tangerang Selatan didapati beberapa dari kalangan mahasiswa nya yang melakukan aktivitas bisnis. Dari bisnis kuliner hingga bisnis barang dan jasa. Berdasarkan hasil wawancara terhadap tujuh mahasiswa yang berwirausaha, maka diketahui latar belakang para wirausahawan ditinjau dari pendidikan, ekspektasi pendapatan, dan motivasi sebagai berikut:

a. Pendidikan

Pengaruh pendidikan kewirausahaan selama ini telah dipertimbangkan sebagai salah satu faktor penting untuk menumbuhkan dan mengembangkan hasrat, jiwa dan perilaku berwirausaha di kalangan generasi muda. ${ }^{25}$ Apabila pendidikan memadai, maka seseorang akan siap untuk menjadi seorang wirausaha dan memimpin anak buahnya. Latar belakang pendidikan seseorang terutama yang terkait dengan bidang usaha, seperti bisnis dan manajemen atau ekonomi dipercaya akan mempengaruhi keinginan dan minatnya untuk memulai usaha baru di masa mendatang. Sebuah studi dari India membuktikan bahwa latar belakang pendidikan menjadi salah satu penentu penting intensi kewirausahaan dan kesuksesan usaha yang dijalankan. ${ }^{26}$

Mengenai hal tersebut Ketua Sekolah Tinggi Ilmu Tarbiah Al-Amin Kreo Tangerang yang menyatakan bahwa pendidikan kewirausahaan sangat penting karena kurikulum saat ini harus ada ciri khas dan muatan lokal, terutama yang diwajibkan adalah yang terkait dengan program pendidikan itu sendiri dan semua program pendidikan apapun harus memberikan materi-materi kewirausahaan. Di kampus ini sudah mulai diterapkan pada materi kewirausahaan berdasarkan SNDIKTI (Standar Nasional Pendidikan Tinggi Kewirausahaan) dan jika sudah terprogram kurikulum kewirausahaan akan diberikan SKPI (Surat Keterangan Pendamping Ijazah) ini akan menjadi nilai tambah bagi jurusan tarbiah. ${ }^{27}$ Pendidikan kewirausahaan bertujuan meningkatkan pengetahuan kewirausahaan mahasiswa yaitu melalui sikap, pengetahuan dan keterampilan yang tertanam dalam kewirausahaan. Pendidikan yang berwawasan kewirausahaan, adalah pendidikan yang menerapkan prinsip-prinsip dan metodologi ke arah pembentukan kecakapan hidup (life skill). Semakin banyak penyediaan-penyediaan pengalaman dan penguasaan mengenai kewirausahaan dengan melibatkan mereka dalam kegiatan belajar, pengembangan rencana bisnis, dan menjalankan usaha kecil yang diberikan kepada individu/mahasiswa, maka semakin tinggi niatnya untuk berwirausaha.

Demikian juga yang dinyatakan oleh salah satu dosen Pembantu Ketua Tiga (Puket III) Sekolah Tinggi Ilmu Tarbiah Al-Amin Kreo Tangerang bagian kemahasiswaan hal tersebut sesuai dengan kurikulum perguruan tinggi yang berbasis

${ }^{25}$ Kourilsky, M. L. dan W. B. Walstad, "Entrepreneurship and female youth: knowledge, attitude, gender differences, and educational practices", Journal of Business Venturing, Vol. 13, No.1 (1998): 77-88.

26 Sinha, T. N., "Human factors in entrepreneurship effectiveness", Journal of Entrepreneurship, Vol.5, No.1(1996): 23-29.

27 Wawancara dengan Zainudin Abdullah, tanggal 4 Agustus 2019. 
KKNI yang mengacu pada Kurikulum Temaresadiksti dan Diktis Kementerian Agama, mahasiswa tidak hanya menguasai bidang ilmu keagamaan tetapi dia juga menguasai disiplin ilmu lain selain ilmu yang linear dengan jurusannya salah satu diantaranya ialah ilmu kewirausahaan maka itu nanti kedepannya lulusan STIT (Sekolah Tinggi Ilmu Tarbiah Al-Amin Kreo Tangerang) Al-Amin ini akan punya Surat Keterangan Pendamping Ijazah (SKPI), yang nanti akan ada kemampuan kewirausahaan mahasiswa dan ini sesuai dengan acuan pemerintah. ${ }^{28}$

Dari pemaparan diatas pendidikan kewirausahaan hendaknya bisa dipertimbangkan sebagai salah satu faktor penting untuk menumbuhkan pola pikir dan jiwa entrepreneur pada mahasiswa, sehingga mahasiswa secara sadar memiliki keberanian untuk mencoba berwirausaha, berfikir untuk menemukan dan mengembangkan ide wirausaha dengan cara melihat peluang usaha yang akan dilakukan. Oleh karena itu pendidikan kewirausahaan di perguruan tinggi sangat penting untuk diterapkan.

Berdasarkan hasil wawancara, para mahasiswa wirausahawan saat ini sedang mengenyam S1 di Sekolah Tinggi Ilmu Tarbiah (STIT) Al-Amin Kreo Tangerang. Mereka semua membuat usaha ketika sedang menempuh pendidikan. Mereka sendiri yang menjalankan dan mengelola usaha sambil kuliah. Hal demikian dinyatakan oleh Irwansyah yang mengatakan dirinya tidak pernah mengenyam pendidikan atau mengambil jurusan yang berkaitan dengan kewirausahaan. Tetapi dia ada keinginan untuk mengetahui lebih dalam ilmu tentang kewirausahaan melalui work shop ataupun seminar-seminar. Kemudian ilmu yang didapat diterapkan dalam praktik wirausahanya. ${ }^{29}$ Hal tersebut dinyatakan pula oleh Sarjono, bahwa dirinya pernah kuliah di jurusan Akuntansi Pajak, yang didalamnya terdapat mata kuliah kewirausahaan.

Dari pengetahuan yang didapat Sarjono selama kuliah maka dia berani mengambil risiko untuk memulai berwirausaha dan ternyata Sarjono memang berpotensi di bidang tersebut. Lain halnya dengan mereka yang mengaku tidak terlalu terpengaruh dengan pendidikan ketika memutuskan untuk berwirausaha. Seperti yang disampaikan oleh Rikha. Rikha memulai bisnis itu hanya sekadar mengisi waktu luang, adapun untuk fokus ke bisnis tersebut tidak terlalu. Karena dirinya seorang pengajar juga sebagai aktivis di organisasi anak muda di lingkungan rumahnya. Rikha menjalankan bisnis tersebut ketika ada waktu luang, kalau tidak ada waktu luang, Rikha mengasih kesempatan ke teman nya untuk membantu menjualkan produknya. ${ }^{30}$ Begitupun yang disampaikan oleh Wawan, yang menjalankan bisnisnya sebagai pengalaman. Karena Wawan sudah terbiasa belajar bisnis sejak duduk dikelas 4 Sekolah Dasar. ${ }^{31}$ Dan demikian juga dengan Hisni yang menjalankan usahanya sebagai usaha sampingan untuk memenuhi kebutuhan hidupnya. Hal tersebut disampaikan pula oleh Ravi dan Eka yang menyatakan hal yang sama. ${ }^{32}$

Berdasarkan hasil wawancara diatas, dapat diketahui bahwa beberapa mahasiswa memang berwirausaha sambil berkuliah. Mereka mengambil pendidikan

\footnotetext{
${ }_{28}$ Wawancara dengan Abdul Aziz, tanggal 9 Agustus 2019.

29 Wawancara dengan Irwansyah, tanggal 14 Juli 2019.

${ }^{30}$ Wawancara dengan Rikha Safira, tanggal14 Juli 2019.

${ }^{31}$ Wawancara dengan Wawan Kurniawan, tanggal 12 Juli 2019.

32 Wawancara dengan Hisni Mubarok, tanggal 14 Juli 2019.
} 
yang bisa mendukung keinginannya tersebut. Pendidikan dapat menjadi sebab mahasiswa memilih berwirausaha. Dari tujuh mahasiswa wirausahawan, keduanya mengaku bahwa pendidikan kewirausahan menjadi dasar keutamaan seseorang dalam memulai wirausaha dan mereka mengatakan bahwa mereka ingin menerapkan ilmu yang telah mereka dapat selama belajar di kampus maupun mengikuti workshop dan seminar tentang kewirausahaan. Sedangkan lima mahasiswa wirausahawan mengaku pendidikan tidak mempengaruhi pilihannya untuk berwirausaha.

\section{Ekspektasi Pendapatan}

Pendapatan adalah penghasilan yang diperoleh seseorang baik berupa uang maupun barang. Berwiraswasta dapat memberikan pendapatan yang dapat digunakan untuk memenuhi kebutuhan hidupnya. Keinginan untuk memperoleh pendapatan itulah yang dapat menimbulkan minatnya untuk berwirausaha. Dalam bisnis, pendapatan adalah jumlah uang yang diterima oleh perusahaan dari aktivitasnya, kebanyakan dari penjualan produk atau jasa kepada pelanggan. Bagi investor, pendapatan kurang penting dibanding keuntungan, yang merupakan jumlah uang yang diterima setelah dikurangi pengeluaran. ${ }^{33}$

Ekspektasi pendapatan adalah harapan seseorang akan pendapatan yang diperolehnya dari kegiatan usaha ataupun bekerja. Ekspektasi atau harapan akan penghasilan yang lebih baik merupakan salah satu faktor yang mempengaruhi apakah seseorang ingin menjadi seorang wirausaha atau tidak. Jika seseorang berharap untuk mendapatkan pendapatan yang lebih tinggi dengan menjadi seorang wirausaha, maka ia akan semakin terdorong untuk menjadi seorang wirausaha. Menjadi seorang wirausaha mengharapkan pendapatan yang tinggi daripada menjadi karyawan perusahaan. Dengan berwirausaha akan mendatangkan pendapatan yang besar dan tidak terbatas, tetapi pendapatan dari berwirausaha tersebut tidak bisa diprediksi, kadang bisa diatas pendapatan yang diharapkannya, kadang pula bisa diluar dari yang pendapatan diharapkannya. Seseorang dengan ekspektasi pendapatan yang lebih tinggi daripada bekerja menjadi karyawan merupakan daya tarik untuk menjadi wirausaha. ${ }^{34}$

Dari tujuh mahasiswa wirausahawan yang penulis wawancarai, terdapat tiga mahasiswa yang mempunyai ekspektasi pendapatan yang tinggi dalam berwirausaha. Mahasiswa yang mempunyai ekspektasi yang tinggi dalam berwirausaha yaitu Ravi, Sarjono, dan Eka. Alasan mereka menjalankan wirausaha salah satunya ialah mendapatkan penghasilan yang tidak monoton seperti gaji karyawan pada umumnya, karena biasanya orang yang berwirausaha mendapatkan penghasilan pertiap harinya meskipun tidak menentu, yang pasti ada pemasukan pertiap hari dan tiap bulannya. Dan pendapatan tersebut bisa untuk memenuhi kebutuhan hidup terutama pada mahasiswa yang ingin belajar hidup mandiri. ${ }^{35}$ Wawan juga mengatakan hal yang sependapat dengan Ravi. Ia menyampaikan dalam wawancara bahwa menjadi seorang

33 Suhartini,Yati, Skripsi Analisis Faktor-faktor Yang Mempengaruhi Minat Mahasiswa Dalam Berwirausaha pada Mahasiswa Universitas PGRI Yogyakarta (Yogyakarta: Universitas PGRI Yogyakarta, 2011), 36.

${ }_{34}$ Sukanti, "Pengaruh Ekspektasi Pendapatan, Lingkungan Keluarga Dan Pendidikan Kewirausahaan Terhadap Minat Berwirausaha", Jurnal Profita, (2016):8.

${ }^{35}$ Wawancara dengan Ravi Deskiansyah, tanggal 12 Juli 2019. 
wirausaha tidak lagi memikirkan pendapatan yang masuk tiap bulannya dari suatu perusahaan akan tetapi, kita sendiri yang mengelola pendapatan itu sendiri sehingga menjadi tidak terbatas pendapatan yang kita terima, bisa jadi lebih besar dari gaji karyawan biasa di suatu perusahaan. ${ }^{36}$

Dalam konteks tersebut juga dinyatakan oleh Eka, Ia mengatakan dalam wawancaranya bahwa tidak bisa hanya mengandalkan satu pekerjaan saja untuk mendapatkan penghasilan, maka dengan berbisnis bisa untuk menambahkan penghasilan tambahan. ${ }^{37}$ Tiga mahasiswa yang memiliki ekspektasi pendapatan yang tinggi mengaku terdorong untuk membangun suatu bisnis, kecuali Rikha, Wawan, Hisni dan Ravi. Hal ini dikarenakan mereka melakukan aktivitas bisnisnya untuk mengisi waktu luang dan belajar mandiri dalam wawancara yang disampaikan bahwa ekspektasi pendapatan yang tinggi tidak menjadi faktor pendorong dalam berbisnis, daripada waktu luang terbuang dengan hal yang kurang bermanfaat, lebih baik digunakan untuk berwirausaha. Selain mendapat penghasilan untuk keperluan seharihari juga bisa belajar mandiri tanpa harus minta uang kepada orang tua". ${ }^{38}$

Dari wawancara diatas dapat disimpulkan bahwa dari tujuh mahasiswa wirausahawan tiga mahasiswa mempunyai ekpektasi terhadap pendapatan yang ingin diterimanya setelah melakukan suatu pekerjaan untuk memenuhi kebutuhan hidup. Sedangkan empat mengaku ekspektasi pendapatan tidak mempengaruhi pilihannya untuk berwirausaha.

\section{Motivasi}

Motivasi dipandang sebagai dorongan mental yang menggerakkan dan mengarahkan perilaku manusia atas dasar kebutuhan. Motivasi berwirausaha akan muncul dalam diri seseorang karena ada keinginan untuk mewujudkan kesuksesan berwirausaha. Motivasi yang tinggi untuk berprestasi dalam berwirausaha akan berpengaruh terhadap minat seseorang untuk berwirausaha sehingga dapat berperan dalam memulai kegiatan kewirausahaan. Indikator untuk mengukur variabel motivasi yaitu mendapat laba, kebebasan, impian personal atau aktualisasi diri, kemandirian, kebutuhan fisiologis, rasa aman, kebutuhan sosial dan kebutuhan akan prestasi. ${ }^{39}$

Dalam konteks tersebut Sarjono menyampaikan bahwa dengan basic awal perkuliahan yang pernah di jurusinya di akuntansi pajak, ada mata kuliah kewirausahaan yang menjadi motivasi bagi dirinya untuk beralih menjadi profesi wirausaha. Dan kewirausahaan telah menjadi passion nya saat ini untuk memenuhi kebutuhan hidupnya seperti menafkahi keluarga dan biaya kuliah. ${ }^{40}$ Menyatakan hal yang demikian sependapat dengan Eka dalam wawancaranya yang disampaikan bahwa selain menjadi mahasiswa bagi dirinya harus punya yang namanya usaha sampingan karena mengambil waktu luang yang tersisa kemudian dimanfaatkan untuk usaha sampingan lebih baik ketimbang dihabiskan untuk hal yang kurang bermanfaat,

${ }^{36}$ Wawancara dengan Wawan Kurniawan, tanggal 12 Juli 2019.

37 Wawancara dengan Eka Purnamasari Tanggal 14 Juli 2019.

38 Wawancara dengan Rikha Safira Tanggal 14 Juli 2019.

39 Peppy Puspita Sari, Pengaruh Ekspektasi Pendapatan, Motivasi, Pendidikan Kewirausahaan, dan Norma Subjektif Terhadap Minat Berwirausaha (Skripsi: Fakultas Ekonomi Universitas Negeri Yogyakarta, 2017), 61

${ }^{40}$ Wawancara dengan Sarjono, tanggal 14 Juli 2019. 
dan tidak terikat dengan waktu. Dan penghasilan dari wirausaha bisa untuk menambah tabungan dan biaya kuliah. ${ }^{41}$ Hal tersebut sependapat dengan Irwansyah dan Hisni yang menjalankan bisnis untuk memenuhi kebutuhan hidup seperti menafkahi keluarga, biayai kuliah dan pendidikan. ${ }^{42}$ Begitu juga yang disampaikan oleh Wawan, Ravi dan Rikha dalam wawancara yang mengatakan bisnis yang dijalaninya untuk melatih kemandirian selain itu juga untuk memenuhi kebutuhan hidup, seperti bayar kuliah, makan sehari-sehari dan untuk keperluan lainnya. ${ }^{43}$

Dari wawancara diatas dapat diketahui bahwa dari tujuh mahasiswa wirausahawan mempunyai motivasi yang tinggi dalam berwirausaha yaitu untuk memenuhi kebutuhan hidup mereka. Seperti menafkahi keluarga, biaya kuliah, dan keperluan hidup sehari-hari. Dalam konteks tersebut dapat diketahui bahwa antara bisnis dan kebutuhan hidup saling berkaitan dan tidak akan pernah terlepas. Seperti yang dinyatakan oleh Ketua Program Pendidikan bahwa kegiatan usaha atau bisnis merupakan suatu aktivitas untuk memenuhi kebutuhan dan keinginan manusia, organisasi, dan masyarakat secara luas. ${ }^{44}$ Hal demikian juga ditanggapi oleh Kepala Bagian Keuangan bahwa mahasiswa yang berwirausaha sambil kuliah karena selain untuk menopang biaya perkuliahan juga untuk memenuhi keperluan sehari-hari yang menjadi kebutuhan hidupnya. ${ }^{45}$

Dari pemaparan diatas dapat disimpulkan bahwa motivasi menjadi salah satu hal yang melatarbelakangi seseorang untuk melakukan sebuah tindakan guna mencapai tujuan tertentu. Motivasi berwirausaha akan muncul dalam diri seseorang karena adanya dorongan untuk mencapai kesuksesan dalam berwirausaha. Seseorang yang memiliki motivasi yang tinggi untuk berhasil dalam bidang wirausaha akan dapat memunculkan minat berwirausaha sehingga ia akan melakukan tindakan guna mencapai tujuan tertentu. Dengan memiliki motivasi yang tinggi maka akan memberikan dampak yang tinggi pula terhadap minat berwirausaha. ${ }^{46}$

\section{Bisnis Mahasiswa Wirausahawan}

Saat ini mahasiswa tidak hanya berperan sebagai pembelajar dan aktivis saja. Telah diketahui bahwa banyak mahasiswa yang turut berperan sebagai seorang pencipta lapangan kerja sekaligus wirausahawan. Mereka membangun bisnis ketika masih duduk dibangku kuliah. Perubahan teknologi terutama dalam bidang informasi dapat mereka manfaatkan demi mendukung terlaksananya bisnis mereka tersebut. Mahasiswa dapat berbisnis melalui market place online yang saat ini tersedia begitu banyak. Selain itu mahasiswa juga dapat melakukan bisnis offline dengan bantuan karyawan. Jenis bisnis yang dilakukan oleh mahasiswa sangat beragam. Mulai dari fashion, hobi, kuliner, properti, gadget sampai perusahaan jasa.

\footnotetext{
${ }^{41}$ Wawancara dengan Eka Purnamasari, tanggal 14Juli 2019.

42 Wawancara dengan Irwansyah, tanggal 14 Juli 2019.

${ }^{43}$ Wawancara dengan Wawan Kurniawan, tanggal 12 Juli 2019.

${ }^{44}$ Wawancara dengan Ahmad Rifai, tanggal 9 Agustus 2019.

${ }^{45}$ Wawancara dengan Ahmad Masruri, tanggal 9 Agustus 2019.

46 Septianingrum, E, R, Pengaruh Pendidikan Kewirausahaan dan Motivasi
} Entrepreneurship terhadap Minat Mahasiswa Akuntansi untuk Berkarier menjadi Entrepreneur (Skripsi: Fakultas Ekonomi Universitas Negeri Yogyakarta, 2010), 56. 
Menurut hasil wawancara, mahasiswa wirausahawan memiliki tiga jenis bisnis. Mereka berbisnis dalam bidang kuliner, fashion serta hobi. Dalam bidang kuliner terdapat bisnis ayam crispy dan warung nasi sambal gledek. Mereka membuat dan mengelola bisnis tersebut dengan bantuan karyawan dan partner. Ravi membuka warung nasi karena nasi menjadi makanan pokok yang akan dibutuhkan setiap harinya, macam-macam yang saya jual ada ayam goreng, berbagai jenis ikan asin, dan lalap tetapi yang menjadi khas dalam kuliner nya yaitu dari sambalnya" 47 Irwansyah menjual berbagai macam ayam, dari mulai ayam geprek, ayam crispy, dan juga ada jus. Dan sudah memiliki dua cabang di masing-masing usaha kuliner yang dijalaninya. ${ }^{48}$

Bisnis kuliner tidak menjadi pilihan bagi mahasiswa dalam berwirausaha. Berbeda Hisni, Sarjono, Wawan, Eka dan Rikha mereka memiliki bisnis di bidang hobi dan fashion. Hisni dan Sarjono mengaku membuat bisnis karena ketertarikan dan passion yang mereka miliki. Mereka mendalami passion mereka tersebut lalu mencoba masuk kedalam dunia wirausaha. Hobi Hisni memang suka berbisnis sejak duduk di bangku SMP. Dan saat ini Hisni menjalankan bisnis pulsa online. Untuk memudahkan orang yang malas pergi ke konter pulsa bisa memalui pulsa online yang dijalaninya. ${ }^{9}$

Berbeda dengan Sarjono yang awal bisnisnya ikut gabung dengan teman. Sampai di tahun 2014 mempunyai cabang sendiri di daerah Rawa Belong, Jakarta Barat. Pesanan rangkaian bunga bervariasi dari buat acara seperti pernikahan, wisuda, pentas seni di sekolah, sampai kartu tanda ucapan dari rangkaian bunga bisa menghubungi Sarjono. Berawal dari hobi sampai menjadi passionnya saat ini..$^{50}$ Kalau Rikha Pertama itu dia bikin koleksi gamis, kemudian di share ke media sosial dan dibuatkannya online shop. ${ }^{51}$

Mereka memilih bisnis yang simpel dan menurut mereka bisnis tersebut dapat dijalankan sambil berkuliah. Selain itu mahasiswa juga melihat potensi yang ada dalam bisnis yang mereka jalankan tersebut. Semua mahasiswa wirausahawan membuat usaha tersebut saat duduk di bangku kuliah. Karena keterbatasan waktu dan tenaga, sekarang mereka mempunyai partner kerja dan beberapa karyawan dalam usahanya. Sarjono menjalankan usaha berdua dengan istrinya, istri yang bagian mengurusi online dan toko, dia dibagian pendekoran bunga. Kalau orderannya lagi banyak, Sarjono meminta bantuan tenaga kerja dari teman, omset yang didapatkannya rata-rata perbulan 30 sampai 35 juta. ${ }^{52}$

Berbeda dengan Wawan saat ini yang mengelola sendiri usahanya dan terkadang dibantu dengan temannya jika sedang banjir orderan. Omsetnya rata-rata kalau lagi rame rata-rata perbulan bisa mencapai 19 juta. ${ }^{53}$ Kalau Ravi mempunyai satu karyawan, untuk membantu melayani pembeli dan dirinya sendiri mengolah makanan dan keuangan. Kalau untuk omsetnya perharinya itu bisa sampai 400 ribu sampai 500 ribu. ${ }^{54}$ Mahasiswa wirausahawan memiliki partner bisnis serta memiliki karyawan

47 Wawancara dengan Ravi Deskiansyah, tanggal 12 Juli 2019.

${ }^{48}$ Wawancara dengan Irwansyah, tanggal 14 Juli 2019.

${ }^{49}$ Wawancara dengan Hisni Mubarok, tanggal 14 Juli 2019.

50 Wawancara dengan Sarjono, tanggal 14 Juli 2019.

51 Wawancara dengan Eka Purnamasari, tanggal 14 Juli 2019.

52 Wawancara dengan Sarjono, tanggal 14 Juli 2019.

${ }^{53}$ Wawancara dengan Wawan Kurniawan, tanggal 14 Juli 2019.

54 Wawancara dengan Ravi Deskiansyah, tanggal 12 Juli 2019. 
untuk membantu jalannya perusahaan. Mahasiswa yang berpartner memulai bisnis dengan uang dan tenaga bersama. Hasil dari usahapun dibagi sesuai dengan jumlah partner yang dimiliki. Dari berbagai jenis usaha yang mereka miliki tersebut, mahasiswa mendapat omset berkisar antara 400 ribu sampai 35 jutaan per bulan. Dari bisnis yang mereka jalankan sambil berkuliah, mahasiswa wirausahawan mendapatan omset yang terbilang besar. Mereka dapat menggaji karyawan, menyewa tempat serta membiayai kuliahnya sendiri. Dari cara pemasarannya, mereka menggunakan media online dan offline. Wawan menggunakan media online tetapi juga mempunyai offline store. Sama seperti Eka dan Rikha juga memilih menggunakan media online seperti shoppie, tokopedia, bukalapak dan offline dalam usahanya. ${ }^{55}$

Berkembangnya berbagai media untuk memasarkan produk mendatangkan keuntungan bagi para mahasiswa. Teknologi yang semakin maju dan semakin memudahkan pelanggan untuk mendapatkan barang membuat pengusaha menjadi untung besar. Apalagi market place tersebut disediakan secara gratis bagi penjual. Mahasiswa memanfaatkan momen tersebut secara tepat sehingga mendatangkan keuntungan bagi perusahaan. Selain menggunakan media online mahasiswa juga memiliki toko fisik untuk menunjang penjualannya. Berdasarkan wawancara tersebut, dapat diketahui bahwa mahasiswa wirausahawan memilih bisnis yang mudah mereka jalankan sambil berkuliah. Mereka berbisnis fashion, hobi, kuliner serta minuman kemasan. Mereka memiliki beberapa karyawan serta partner kerja untuk mempermudah jalannya kegiatan usaha. Omset rata-rata para mahasiswa berkisar antara 400 ribu sampai 35 juta per bulan. Mereka menggunakan media online serta offline dalam menjalankan usahanya.

\section{Kendala Saat Membangun Bisnis}

Dalam membangun suatu bisnis tentu seseorang akan mendapat beberapa masalah. Membuat bisnis akan melalui beberapa proses. Mereka akan membutuhkan suatu ide, uang, waktu, tenaga, dan ilmu dalam menjalankan usaha. Saat usaha berdiri, mereka akan menghadapi ketidakpastian pendapatan dalam bisnis. Wirausahawan harus pandai mengatur keuangan agar tidak mengalami kerugian. Terlebih lagi jika ada keadaan darurat yang menimpa usaha mereka. Mereka harus siap jika suatu saat tertimpa masalah yang tidak dapat diprediksikan sebelumnya.

Menurut hasil wawancara terhadap mahasiswa wirausahawan, terdapat beberapa tantangan dan masalah dalam membuat sebuah bisnis. Tantangan pertama yang dihadapi oleh mahasiswa adalah keterbatasan modal berupa uang. Sebagai seorang mahasiswa, mereka tentu belum mempunyai penghasilan sebagai modal untuk membangun bisnis. Tantangan ini disampaikan oleh beberapa mahasiswa. Awal mula yang dirasakan Ravi kendalanya di modal. Ketika ingin di jalankan tetapi belum ada modalnya. Sedikit demi sedikit mencari modal baru bisa buka usaha. ${ }^{56}$ Hal tersebut dinyatakan pula oleh Sarjono yang mempunyai keinginan sebelum lulus kuliah harus mempunyai usaha. ${ }^{57}$

Modal merupakan kebutuhan yang wajib ada bagi seorang pengusaha. Mereka tidak bisa menghasilkan suatu produk tanpa modal uang. Selain modal, mahasiswa

\footnotetext{
55 Wawancara dengan Eka Purnamasari, tanggal 14 Juli 2019

56 Wawancara dengan Ravi Deskiansyah, tanggal 12 Juli 2019.

57 Wawancara dengan Sarjono, tanggal 14 Juli 2019.
} 
juga mempunyai masalah tentang pembagian waktu. Karena mereka masih berkuliah saat membangun bisnis, maka waktu yang mereka punya pun terbatas. Peran ganda sebagai mahasiswa dan wirausahawan membuat waktu mereka berkurang. Pengelolaan awal yang dijalankan Hisni masih belum tersusun rapi. ${ }^{58}$ Berbeda yang dialami oleh Irwansyah, Kendala yang dihadapinya saat ini di semester delapan dengan skripsi ini. Irwansyah mengatakan dalam wawancaranya memang harus bisa mengatur waktu dengan baik antara bisnis dengan kuliah. ${ }^{59}$ Selanjutnya kendala yang dihadapi Eka yaitu waktu karena harus bisa membagi antara waktu berbisnis dengan kuliah. ${ }^{60}$

Begitu pula yang disampaikan oleh Wawan yang mengalami kendala saat harus bisa membagi waktu bisnis dengan kuliah. ${ }^{61}$ Mahasiswa mengatakan bahwa waktu kuliah terganggu dengan pilihannya membangun suatu usaha. Mereka kekurangan waktu untuk belajar karena membangun usaha membutuhkan waktu yang banyak. Mahasiswa wirausahawan lebih memilih menyampingkan kuliah dan memprioritaskan pembuatan usahanya. Mereka menjadi tidak terlalu fokus pada kuliah. Kegiatan belajar mereka pun terganggu. Akibatnya beberapa mahasiswa mengalami penurunan nilai. Akan tetapi pengorbanan mereka tersebut terbayar dengan suksesnya usaha yang mereka buat. Hasil dari usaha dapat mereka gunakan untuk membiayai kuliah dan keperluan sehari-hari. Berdasarkan wawancara di atas, mahasiswa wirausahawan memiliki berbagai tantangan pada saat membangun usaha. Mereka terkendala oleh modal uang ketika akan menciptakan sebuah usaha. Selain modal, mahasiswa juga terkendala oleh waktu yang terbatas. Terakhir, sebagai mahasiswa mereka memiliki tanggung jawab untuk belajar juga.

\section{KESIMPULAN}

Berdasarkan hasil penelitian kualitatif dengan teknik observasi, wawancara dan dokumentasi yang dilaksanakan di Sekolah Tinggi Ilmu Tarbiah Al-Amin Kreo Tangerang tentang aktivitas bisnis dikalangan mahasiswa dapat diambul kesimpulan. Kesimpulan tersebut dapat dipaparkan sebagai berikut: 1) Mahasiswa wirausahawan memiliki aktivitas bisnis yang berbeda-beda. Dari bisnis kuliner, fashion, hingga barang dan jasa; 2) Bisnis yang diambil mahasiswa sambil berkuliah didapati beberapa hal yang menjadi pilihan mahasiswa untuk berwirausaha. Pendidikan, Ekspektasi Pendapatan, dan Motivasi. Motivasi berpengaruh terhadap pilihan mahasiswa untuk berwirausaha. Pendidikan tidak terlalu berpengaruh terhadap pilihan berwirausaha. Mahasiswa yang memiliki latar pendidikan tertarik berwirausaha karena jurusan yang pernah diambil serta workshop ataupun seminar yang pernah diikuti. Beberapa dosen Sekolah Tinggi Ilmu Tarbiah Al-Amin Kreo Tangerang sangat mendukung terhadap mahasiswa yang berwirausaha. Mahasiswa wirausahawan dinilai positif oleh dosen karena selain sambil kuliah mereka juga mendapatkan pengalaman, menambah relasi sosial, dan penghasilan tambahan yang sangat bermanfaat untuk memenuhi kebutuhan mereka. Sebagian dari mahasiswa wirausahawan mereka ada yang berprofesi sebagai guru, karyawan, dan ibu rumah tangga. Profesi memiliki andil terhadap pilihan

\footnotetext{
58 Wawancara dengan Hisni Mubarok, tanggal 14 Juli 2019.

59 Wawancara dengan Irwansyah, tanggal 14 Juli 2019.

${ }^{60}$ Wawancara dengan Eka Purnamasari, tanggal 14 Juli 2019.

${ }^{61}$ Wawancara dengan Wawan Kurniawan, tanggal 12 Juli 2019.
} 
mahasiswa untuk berwirausaha. Selain ekspektasi pendapatan yang tinggi juga ingin menambah penghasilan dari gaji profesi mereka. Akan tetapi mahasiswa yang belum memiliki profesi atau pekerjaan, ekspektasi pendapatan tidak mempengaruhi minatnya untuk berwirausaha. Karena bagi mahasiswa wirausahawan yang belum memiliki profesi, penghasilan yang didapat dari usahanya hanya untuk memenuhi kebutuhan sehari-hari mereka yang ingin belajar mandiri tanpa harus meminta kepada orang tua. Motivasi membawa dampak yang baik untuk perkembangan diri mahasiswa, khususnya untuk masalah kewirausahaan. Motivasi berperan sebagai pendorong mahasiswa atas dasar kebutuhan; 3) Mahasiswa wirausahawan menjadikan laba bisnisnya untuk kebutuhan hidupnya seperti bayar kuliah, menafkahi keluarga, dan keperluan sehari-hari. Karena antara bisnis dengan kebutuhan hidup saling berkaitan dan tidak akan pernah terlepas dari aktivitas kewirausahawan. 


\section{DAFTAR PUSTAKA}

Alhaji, Abdul, "Entrepreneurship Education And Its Impact On Self Employment Intention And Entrepreneurial Self-Efficacy", Journal Humanities And Social Sciences, Vol. 3, No.1. 2011.

Alma, Buchari, Kewirausahaan, Bandung: Alfabeta, 2010.

A. L., Politis, D., Winborg, J. \& Dahlstrand, "Exploring the Resource Logic of Student Entrepreneurs", International Small Business Journal, Vol. 30, No. 6, 2012.

Aripin, Strategi Dakwah H. Dasuki dalam Membangun Wirausaha Muslim di Wilayah Cakung Jakarta Timur, Semarang, Skripsi IAIN Walisongo, 2011.

Ashfahani, Salim Siagian, "Kewirausahaan Indonesia dengan semangat 17 Agustus 1945", Kloang Klede Jaya PT Putra Timur bekerjasama dengan Puslatkop dan PK Depkop dan PPK, Jakarta, 1945.

Atsan, Gurol “Entrepreneurial Characteristics Amongst University Students, Some Insights for Entrepreneurship Education and Training in Turkey", Education and Training, Vol. 48, No.1, 2006.

A. L., Politis, D., Winborg, J. \& Dahlstrand, "Exploring the Resource Logic of Student Entrepreneurs", International Small Business Journal, Vol. 30, No. 6, 2012.

Aziz, Abdul, Etika Bisnis Perspekitif Islam: Implementasi Etika Islam untuk Dunia Usaha, Bandung: AL-Fabeta, 2013.

Bachri S, Bachtiar, “Meyakinkan Validitas Data Melalui Triangulasi Pada Penelitian Kualitatif" Jurnal Teknologi Pendidikan, Vol.10, No.1, 2010.

Busro, Muhammad, Teori-Teori Manajemen Sumber Daya Manusia, Jakarta: Prenadamedia Group, 2018.

C., Praag, Van, M., "Business Survival and Success of Young Small Business Owners", Tinbergen institite discussion paper, Vol. 3, No. 50, 2003.

Basrowi, Kewirausahaan untuk Perguruan Tinggi , Bogor: Ghalia Indonesia, 2011.

Bayu, Katib, Yuyus Suryana, Kewirausahaan: Pendekatan Karakteristik Wirausahawan Sukses, Jakarta: Kencana Prenada Media Group, 2010.

D, Ricardo, On the Principles of Political Economy and Taxation, London: John Murray, 1817.

DA, Stheperd, Hisrich, RD., Peters, MP., Kewirausahaan Terjemahan Edisi 7 , Jakarta: Salemba Empat 2008.

Djaali, Psikologi Pendidikan, Jakarta: Bumi Aksara, 2007.

Djakfar, Muhammad, Etika Bisnis, Jakarta: Penebar Plus, 2012.

E. Hagen, "The Entrepreneurs as Rebel Against Traditional Society", Human Organization, Vol. 19, No. 4, 1960.

El Adawiyah, Sa'diyah, Buku Ajar Human Relations, Yogyakarta: Deepublish, 2019.

EM, Ruffino, Bartono PH, Teknik Supervisi dan Uji Kompetensi untuk Pendidikan Pariwisata, Yogyakarta, CV. Andi Offset, 2010.

Fauroni, Lukman dan Muhammad, Visi al-Qur'an tentang Etika dan Bisnis, Jakarta: Salemba Diniyah, 2002.

Fitria, Lestari, "Pengaruh jiwa kewirausahaan dan kreativitas terhadap keberhasilan usaha pada sentra industri rajutan Binong Jati Bandung", Available at elib. unikom. ac. Id, Vol. 8, 2011.

Fitrianty, Eriawaty, "Peran Mata Kuliah Kewirausahaan dalam Menumbuhkan Jiwa Wirausaha Mahasiswa Pendidikan Ekonomi", Jurnal Profit, Vol.3, No.3, 2016.

Fuad, Muhammad, Pengantar bisnis, Jakarta, Gramedia Pustaka Utama, 2006. 
G. Egon dan Lincon Yvonna S, Naturalistic Inquiry, Newbury Park: SAGE, 1985.

Ghok, Chu, Kara, Zhu," Chinesse entrepreneurs, motivations, success factors, problems and business-related stress", Journal of Chinese Entrepreneurship, Vol. 3, No.2, 2011.

Hendro, Dasar-dasar Kewirausahaan, Jakarta: Erlangga, 2011.

Hongdiyanto, Charly, "Identifikasi Kepemilikan Entrepreneurial Spirit Mahasiswa Universitas Ciputra dari Kawasan Timur Indonesia", 2014.

Ika, Pratiwi, "Peran Mata Kuliah Kewirausahaan Dalam Mengembangkan Minat Berwirausaha Pada Mahasiswa Fakultas Ekonomi Dan Bisnis Islam Pogram Studi Ekonomi Syariah", Skripsi IAIN Palopo, 20`18.

Iskandar, Dea Tantyo, Solehudin Murpi, Manajemen bisnis untuk orang awam, Jakarta: Laskar Aksara, 2011.

Izzati, Nurul, "Motif Penggunaan Gadget Sebagai Sarana Promosi Bisnis Online di Kalangan Mahasiswa UIN Sunan Kalijaga", Jurnal Komunikasi ASPIKOM, Vol. 2, No. 5, 2015.

J.W., Stewart, W.H., Watson, W.E., Carland, J.C. \& Carland "A proclivity for entrepreneurship: A comparison of entrepreneurs, small business owners, and corporate managers", Journal of Business Venturing, Vol. 14, 1998.

Judge, Timothy A and Robbins Stephen. P, Perilaku Organisasi Organizational Behavior, Jakarta:Salemba Empat, 2008.

Juliyani, Erly, "Etika Bisnis dalam Perspektif Islam", Jurnal Ummul Qura, Vol. 7, No. 1, 2016

Knopp, Sari, Robert Bogdan Biklen, Qualitative Research for Education: An Introduction to Theory and Methods, Boston: Allyn and Bacon. 2013.

Kristanto, Kewirausahaan Entrepreneurship Pendekatan Manajemen dan Praktik, Yogyakarta: Graha Ilmu, 2009.

Kurniawan, Rahmat, "Pengaruh Penerapan Model Pembelajaran Teaching Factory 6 Langkah (TF-6M) dan Prestasi Belajar Kewirausahaan Terhadap Minat Wirausaha", INVOTEC, Vol. 10, No. 1, 2014.

Lexy, Moleong J, Metode Penelitian Kualitatif, Bandung, PT. Remaja Rosda Karya, 2007.

M.M, Srihastuti, Winkel, WS, Bimbingan dan Konseling di Institusi Pendidikan, Yogyakarta, Media Abadi, 2004.

Masruri, Ahmad Kepala Bagian Tata Usaha, Wawancara, 9 Agustus 2019.

Margunan, Ahmad Tri Atmaja, "Analysis Pengaruh Pendidikan Kewirausahaan dan Aktivitas Wirausaha Terhadap Minat Berwirausaha Mahasiswa Universitas Negeri Semarang", Economic Education Analysis Journal, Vol. 5, No. 3, 2016.

Meredith, Gall D an Kamus al-Munawwir, Yogyakarta: Pustaka Progresif, 1984.d other, Educational Research: An Introduction7th eds, Boston, Pearson Education, 2003.

Merriam, Sharan B, Qualitative Research: A Guide to Design and Implementation, USA, The Jossey-Bass, 2009.

Michael, Hubermen, dan Milles M, Analisis data Kualitatif, Jakarta: Universitas Indonesia, 1992.

Mubin, Falihul, Faktor-Faktor yang Memengaruhi Minat Wirausaha Mahasiswa, Diss. UIN Sunan Ampel Surabaya, 2014.

Murpi, Solehuddin, Business Plan praktis dan Dahsyat untuk UMKM, Bekasi, Laskar Aksara, 2011.

Muslich, Etika Bisnis Islami; Landasan Filosofis, Normatif, dan Substansi Implementatif, Yogyakarta: Ekonisia Fakultas Ekonomin UII, 2004.

Munawar, Rosmiati, Donny Teguh Santosa Junias, "Sikap, Motivasi dan Minat Berwirausaha Mahasiswa", Jurnal Manajemen dan Kewirausahaan, Vol. 17, No. 1, 2015. 
N. Franke, Luthje, C., “The Making' of an Entrepreneur: Testing a Model of Entrepreneurial Intent Among Engineering Students at MIT", Research \& Development Management, Vol. 33, No. 2, 2003.

Naqvi, Syed Nawab Naqvi, Etika dan Ilmu Ekonomi, Suatu Sintesis Islami, terjemahan Husin Anis, Bandung: Mizan, 1993.

Nisa, Kara, "15 Ide Bisnis untuk Mahasiswa dengan Potensi Penghasilan Tinggi", 15 Ide Bisnis untuk Mahasiswa dengan Potensi Penghasilan Tinggi", Blog.mokapos.com/2018/07/30/15-ide-bisnis-untuk-mahasiswa-dengan-potensi-penghasilantinggi, (diakses pada 22 Agustus 2019).

Saihu, "Pendidikan Karakter Berbasis Kearifan Lokal (Studi di Jembrana Bali)", Jurnal Pendidikan Islam, Vol. 8, No.1, 2019.

Sari, Puspita Sari, Pengaruh Ekspektasi Pendapatan, Motivasi, Pendidikan Kewirausahaan, dan Norma Subjektif Terhadap Minat Berwirausaha, Skripsi \, Fakultas Ekonomi Universitas Negeri Yogyakarta, 2017.

Sarosa, Pietra, Becoming Young Entrepreneur Dream Big, Start Small, Act Now, Jakarta, Elex Media Komputindo, 2005.

Sinaga, Dearlina, Kewirausahaan; Pedoman untuk Kalangan Praktisi dan Mahasiswa, Yogyakarta, Ekuilibria, 2016.

Sinha, T. N., "Human factors in entrepreneurship effectiveness", Journal of Entrepreneurship, Vol.5, No.1, 1996.

Siswo, Wiratno, "Pelaksanaan pendidikan kewirausahaan di pendidikan tinggi", Jurnal Pendidikan dan Kebudayaan, Vol. 18, No. 4, 2012.

Soegoto, Eddy, Entrepreneurship Menjadi Pembisnis Ulung, Jakarta: Elex Media Computindo, 2009.

Suhartini, Yati, Skripsi Analisis Faktor-faktor Yang Mempengaruhi Minat Mahasiswa Dalam Berwirausaha pada Mahasiswa Universitas PGRI Yogyakarta, Yogyakarta, Universitas PGRI Yogyakarta, 2011.

Sukanti, "Pengaruh Ekspektasi Pendapatan, Lingkungan Keluarga Dan Pendidikan Kewirausahaan Terhadap Minat Berwirausaha", Vol. 1, No. 4, Jurnal Profita, 2016.

Sukidjo. Membudayakan Kewirausahaan. WUNY Majalah Ilmiah Populer, 2011.

Sularto, Agustina, "Intensi kewirausahaan mahasiswa (Studi perbandingan antara fakultas ekonomi dan fakultas ilmu komputer", Proceeding PESAT, Psikologi, Ekonomi, Sastra, Arsitektur, E Sipil, Universitas Gunadarma, Vol. 4, No.3, 2011.

Wawancara dengan Abdul Aziz Tanggal 9 Agustus 2019.

Wawancara dengan Ahmad Rifai Tanggal 9 Agustus 2019.

Wawancara dengan Ahmad Masruri Tanggal 9 Agustus 2019.

Wawancara dengan Eka Purnamasari Tanggal 14 Juli 2019.

Wawancara dengan Hisni Mubarok Tanggal 14 Juli 2019.

Wawancara dengan Irwansyah Tanggal 14 Juli 2019.

Wawancara Ravi Deskiansyah Tanggal 12 Juli 2019.

Wawancara dengan Rikha Safira Tanggal 14 Juli 2019.

Wawancara dengan Zainudin Abdullah Tanggal 4 Agustus 2019. 